\title{
Acute L-Arginine supplementation does not increase nitric oxide production in healthy subjects
}

Thiago Silveira Alvares ${ }^{1,2^{*}}$, Carlos Adam Conte-Junior ${ }^{1}$, Joab Trajano Silva ${ }^{1}$ and Vânia Margaret Flosi Paschoalin ${ }^{1}$

\begin{abstract}
Dietary supplements containing L-arginine have been marketed with the purpose of increasing vasodilatation, and thus, blood and oxygen supply to the exercising muscle. The present study evaluated the acute effect of L-arginine supplementation on indicators of $\mathrm{NO}$ production, nitrite $\left(\mathrm{NO}_{2}^{-}\right)+$nitrate $\left(\mathrm{NO}_{3}^{-}\right)(\mathrm{NOx})$, in healthy subjects. Plasma concentrations of asymmetric dimethylarginine (ADMA) and symmetric dimethylarginine (SDMA) have also been addressed. Seventeen healthy males participated in a randomized, double-blind, placebo-controlled study. Blood samples were drawn from a left antecubital vein at baseline (T0). Afterwards, subjects were randomly submittedto $6 \mathrm{~g}$ of oral L-arginine supplementation (as L-arginine hydrochloride) or placebo (as corn starch); afterwards, the subjects remained at rest in supine position and blood samples were drawn again at 30 (T1), 60 (T2), 90 (T3) and 120 minutes (T4) after supplementation. To analyze $\mathrm{NO}$ production, $\mathrm{NO}_{3}^{-}$was converted to $\mathrm{NO}_{2}^{-}$by nitrate reductase, followed by the derivatization of $\mathrm{NO}_{2}^{-}$with 2,3-diaminonaphthalene. NOx, ADMA and SDMA were analyzed using a high-performance liquid chromatography system and monitored with a fluorescence detector. Two-way ANOVA with repeated measures showed no significant changes in NOx concentrations on the L-arginine group as compared to placebo group at any of the fivetime points (TO: $17.6 \pm 3.9 \mathrm{vs} 14.6 \pm 2.3 \mu \mathrm{mol} / \mathrm{L} ; \mathrm{T1}$ : $15.8 \pm 2.4 \mathrm{vs}$ $14.3 \pm 1.7 \mu \mathrm{mol} / \mathrm{L} ; \mathrm{T} 2: 16.8 \pm 4.9$ vs $13.7 \pm 2.7 \mu \mathrm{mol} / \mathrm{L} ; \mathrm{T} 3: 16.7 \pm 3.9 \mathrm{vs} 14.6 \pm 2.1 \mu \mathrm{mol} / \mathrm{L} ; \mathrm{T} 4: 15.1 \pm 2.8 \mathrm{vs}$ $13.5 \pm 3.5 \mathrm{mmol} / \mathrm{L})$. Furthermore, plasma levels of ADMA and SDMA were not statistically significant between the L-arginine and placebo groups at T0 ( $0.43 \pm 0.19$ vs $0.39 \pm 0.15 \mu \mathrm{mol} / \mathrm{L}$ and $1.83 \pm 1.13 \mathrm{vs} 1.70 \pm 0.62 \mu \mathrm{mol} / \mathrm{L})$, respectively. In conclusion, acute L-arginine supplementation does not increase plasma concentration of NOx in healthy individuals with normal plasma concentrations of ADMA.
\end{abstract}

Keywords: Amino acids, Nitric oxide, Asymmetric dimethylarginine, Symmetric dimethylarginine, Nitrite, Nitrate, HPLC

\section{Introduction}

Many supplements have been introduced in the market with the purpose of enhancing athletes' performance [1]. Most of these supplements allegedly help athletes tolerate a higher degree of heavy training by helping athletes recover faster during intense sport training [2]. Recently, supplements containing L-arginine have been introduced

\footnotetext{
* Correspondence: alvares@iq.ufrj.br

${ }^{1}$ Laboratory of Advanced Analysis in Biochemistry and Molecular Biology, Department of Biochemistry, Chemistry Institute, Federal University of Rio de Janeiro, Brazil

2Present address: Laboratório de Análises Avançadas em Bioquímica e Biologia Molecular, Departamento de Bioquímica - Instituto de Química, Universidade Federal do Rio de Janeiro, Avenida Athos da Silveira Ramos, 149 Centro de Tecnologia, Bloco A, Sala 545, llha do Fundão, Rio de Janeiro, RJ 21941-909, Brazil
}

(c) 2012 Alvares et al.; licensee BioMed Central Ltd. This is an Open Access article distributed under the terms of the Creative Commons Attribution License (http://creativecommons.org/licenses/by/2.0), which permits unrestricted use, distribution, and reproduction in any medium, provided the original work is properly cited.

in the market claiming to promote vasodilatation by increasing nitric oxide $(\mathrm{NO})$ production via nitric oxide synthase (NOS) activation. This vasodilatation would favor an increase perfusion as well as a higher nutrient and oxygen delivery to the active muscles during exercise, enhancing protein synthesis and muscle recovery [2].

L-arginine is considered a semi-essential amino acid because the body normally produces it in sufficient amounts. However, supplementation may be needed in special conditions such as malnutrition, excessive ammonia production, burns, infections, peritoneal dialysis, rapid growth, urea synthesis disorders, and/or sepsis [3].

Physiological concentrations of L-arginine in healthy individuals are enough to saturate endothelial NOS, which is $\sim 3 \mu \mathrm{mol} / \mathrm{L}$. Therefore, supplementary L- 
arginine should not promote increased enzyme activity; consequently, no further NO production should occur. However, there is evidence describing the NO-mediated biological effects associated with L-arginine supplementation despite the fact that nitric oxide synthase (NOS) is theoretically saturated with the physiological concentration of L-arginine-hence the condition known as the 'L-arginine paradox' [4].

Early evidence suggests that L-arginine supplementation may help treat individuals with atherosclerosis risk factors, such as hypercholesterolemia, hypertension, diabetes mellitus, kidney failure, hyperhomocysteinemia, smoking, and aging - all of which are conditions that are associated with reduced NO biosynthesis [5-9]. Böger R., [10] had shown that plasma levels of asymmetric dimethylarginine (ADMA), an endogenous NOS inhibitor, are increased approximately $2-3$ fold in the pathophysiological conditions associated with cardiovascular disease. For this reason, elevated ADMA concentration may be one possible explanation for endothelial dysfunction and decreased NO synthesis in this disease cluster. Therefore, it appears that only subjects with poor NO synthesis are likely to benefit from L-arginine supplementation.

Despite the theory regarding L-arginine supplementation improving vasodilatation from increased NO production, a recent review [2] about the ergogenic effect of L-arginine supplementation in healthy subjects shows that there were only five studies that evaluated exercise performance after acute L-arginine supplementation, three of which reported significant improvements. Besides the improvements observed in physical performance, the authors of these studies did not measure the underlying mechanism that could explain how the results obtained may have been due to increased NO production.

Bailey et al., [11] observed significant increases in the time to task failure with concomitant reductions in the $\mathrm{O} 2$ cost of moderate-intensity cycle exercise and slow oxygen uptake component amplitude on the group supplemented with $6 \mathrm{~g}$ of L-arginine, $1 \mathrm{~h}$ before a series of moderate- and severe-intensity exercise bouts for 3 days. Stevens et al., [12] observed significant increase in peak torque, total work and fatigue index after supplementing with a product containing $6 \mathrm{~g}$ of L-arginine in three equal aliquots at 45,30 and 10 -min periods before isokinetic dynamometer exercise. Buford and Koch, [13] observed significant improvement of average power during repeated sets of supra-maximal exercise during cycle ergometer on the group that consumed $6 \mathrm{~g}$ of L-arginine.

Based on the theory that physiological concentrations of L-arginine are enough to saturate endothelial NOS and no further NO production should occur in healthy individuals, it is our hypothesis that there should be no change inplasma concentration of $\mathrm{NO}_{2}^{-}$and $\mathrm{NO}_{3}^{-}$as a result of L-arginine supplementation when compared to placebo.

Due to the fact that other studies have demonstrated vascular and exercise performance benefits after Larginine supplementation in healthy individuals $[2,14]$, the question still remains as to whether this effect is NO-mediated. Therefore, in order to test the claim that L-arginine supplementation may increase NO synthesis, the present study was conducted to identify the acute effects of L-arginine supplementation on indirect markers of $\mathrm{NO}$ synthesis- $\mathrm{NO}_{2}^{-}$and $\mathrm{NO}_{3}^{-}$. It is to point out that, contrary to the present study, other studiesthat evaluated the effect of L-arginine supplementation on NO synthesis at rest have methodological limitations [15] (e.g.: They did not control diet for food contain $\mathrm{NO}_{2}^{-}$and $\mathrm{NO}_{3}^{-}$, which may cause flaws in the results. The plasma levels of ADMA and SDMA at the beginning of the study have also been addressed.

\section{Methods \\ Subjects}

Seventeen healthy males $(25.5 \pm 3.5 \mathrm{yr}, 78.7 \pm 10.5 \mathrm{~kg}$; $176.1 \pm 7.5 \mathrm{~cm}$ and $\left.25.3 \pm 2.3 \mathrm{~kg} . \mathrm{m}^{-2} \mathrm{BMI}\right)$ were recruited to participate in the study. All subjects were fully informed of the nature and purpose of the investigation and gave their written consent to participate. The exclusion criteria for participation in the study were any known cardiovascular, pulmonary or metabolic diseases (asthma, diabetes, hypertension, dyslipidemia etc.), and the use of nutritional and pharmacological ergogenics. All experimental procedures were performed in accordance with the ethical standards of the Helsinki Declaration and were approved by the Institutional Ethics Committee of the Hospital Universitário Clementino Fraga Filho (protocol \# 0118.0.197.000-10) from Rio de Janeiro, Brazil.

\section{Experimental design}

In a randomized, double-blind and placebo-controlled study, subjects reported to the laboratory. Blood samples were drawn from an antecubital forearm vein at baseline after a ten-minute period of quiet rest in supine position. Afterwards, subjects were randomly divided into either a placebo or an L-arginine group and rested again in supine position in a quiet room. Blood samples were drawn again at 30 (T0), 60 (T1), 90 (T2) and 120 minutes (T4) after supplementation (see Figure 1). During this period, the subjects consumed no food and drink.

\section{Dietary control}

One day before conducting the study, the subjects were oriented as to the $\mathrm{NO}_{2}^{-}$and $\mathrm{NO}_{3}^{-}$content of foods and 


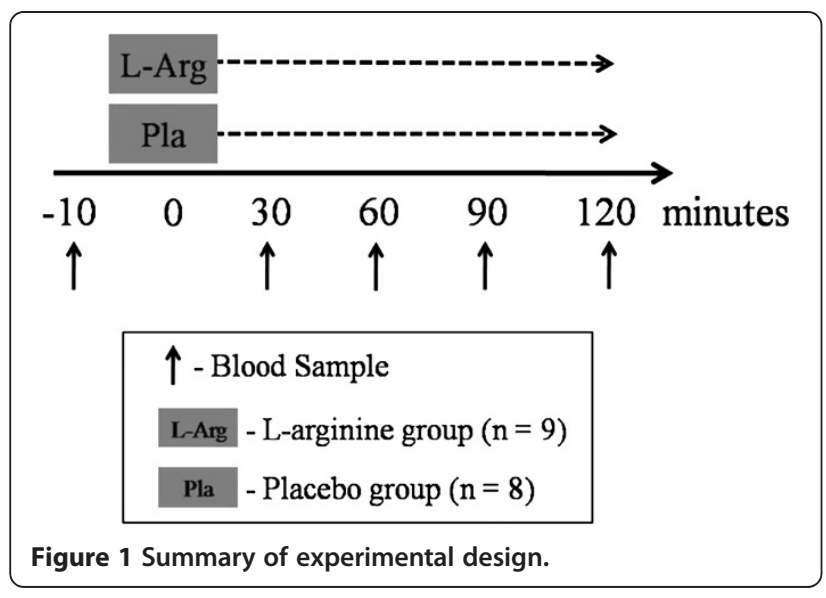

were requested to restrict their diets from foods rich in $\mathrm{NO}_{2}^{-}$and $\mathrm{NO}_{3}^{-}$. A list describing foods and groups of food to be avoided and to be preferred was distributed to the subjects, in order to simplify their dietary choices for low $\mathrm{NO}_{2}^{-}$and $\mathrm{NO}_{3}^{-}$foods for the 24-hour period prior to the study. In short, the subjects were advised to avoid vegetable products, such as spinach and squash, which contain the highest amounts of $\mathrm{NO}_{3}^{-}$per serving. Sweets, nuts, fats and oils contain very little $\mathrm{NO}_{3}^{-}$per serving and were thus permitted. Red meat (beef, pork, lamb, mutton, and liver) and bean products contain the highest amounts of dietary $\mathrm{NO}_{2}^{-}$per serving and were to be avoided. Negligible sources of dietary $\mathrm{NO}_{2}^{-}$are found in cottage cheese, fats such as butter or margarine, and various fruit juices. This dietary orientation was based on a list developed to estimates of dietary $\mathrm{NO}_{2}^{-}$and $\mathrm{NO}_{3}^{-}$ [16]. Adherence to the diet was controlled by twentyfour-hour recall conducted upon arrival for the study, in which each subject was interrogated as to their dietary intake for the $24 \mathrm{~h}$ period prior to arrival for the study. Further analysis of energy intake and macronutrients (as a percentage of total energy) from the twenty-four-hour recall of each subject of both $\mathrm{L}$-arginine and placebo groups was performed by using a nutrition analysis software program (dietWin Professional 2008 for windows, version 2.0, Porto Alegre, RS, Brazil).

\section{Supplementation}

Ten minutes after baseline blood sample, all subjects were orally administered either $6 \mathrm{~g}$ of encapsulated Larginine hydrochloride or placebo (as corn starch) in identical forms with $400 \mathrm{~mL}$ of $\mathrm{H}_{2} \mathrm{O}$ Milli-Q in a double-blind and randomized manner. We chose to provide $6 \mathrm{~g}$ of $\mathrm{L}$-arginine, because such a dose would be well-tolerated when consumed orally, and was reported to increase vasodilatation [17].

\section{Nitric oxide production}

The blood was drawn from antecubital veins and collected in EDTA-containing tubes, and then immediately centrifuged at $3000 \mathrm{~g}$ for $10 \mathrm{~min}$ at $4^{\circ} \mathrm{C}$ in order to separate the plasma, before storing it at $-80^{\circ} \mathrm{C}$ for later analysis. NO production was assayed by measuring plasma $\mathrm{NO}_{2}^{-}+\mathrm{NO}_{3}^{-}(\mathrm{NOx})$ as previously described by $\mathrm{Li}$ et al. [18]. In brief, plasma was diluted in a proportion of 1:10 and 1:100 in order to analyze $\mathrm{NO}_{2}^{-}$and $\mathrm{NO}_{3}^{-}$, respectively. After dilution, $1 \mathrm{~mL}$ of each sample were filtered using a 10-kDa cutoff ultrafilter (Vivaspin 2, GE Healthcare $^{\circledR}$ ) at $14000 \mathrm{~g}$ for $15 \mathrm{~min}$ to remove high-molecular weight proteins. $\mathrm{NO}_{3}^{-}$was converted to $\mathrm{NO}_{2}^{-}$enzymatically by nitrate reductase EC 1.6.6.2 (Roche Diagnostics, Mannheim, Germany) from Aspergillus species. The solution, which consisted of $200 \mu \mathrm{L}$ of sample, $120 \mu \mathrm{M}$ $\mathrm{NADPH}$ and $2 \mu \mathrm{M}$ FAD, was incubated at room temperature for $1 \mathrm{~h}$. Following the conversion of $\mathrm{NO}_{3}^{-}$to $\mathrm{NO}_{2}^{-}$, the sample was incubated at $24^{\circ} \mathrm{C}$ with $316 \mathrm{mM}$ 2,3-diaminonaphthalene to convert $\mathrm{NO}_{2}^{-}$into the highly fluorescent 2,3-naphthotriazole followed by addition of $2.8 \mathrm{M} \mathrm{NaOH}$ and immediately analyzed by highperformance liquid chromatography (HPLC). The HPLC device was equipped with a $5-\mu \mathrm{m}$ reversed-phase $\mathrm{C} 8 \mathrm{col}-$ umn Discovery ${ }^{\circledR}(150 \times 4,6 \mathrm{~mm}$, I.D.) guarded by a 40 $\mu \mathrm{m}$ reversed-phase C18 guard column Ascentis ${ }^{\circledR}(50 \mathrm{x}$ 4,6 mm, I.D.) and a fluorescence detector model RF10AXL (Shimadzu ${ }^{\circledR}$ ) monitoring excitation and emission wavelengths at $375 \mathrm{~nm}$ and $415 \mathrm{~nm}$, respectively. Both columns were obtained from Supelco (Bellefonte, PA, USA). The mobile phase $(1.0 \mathrm{~mL} / \mathrm{min})$ was $15 \mathrm{mM}$ sodium phosphate buffer ( $\mathrm{pH}$ 7.5) and methanol.

Oxidation of $\mathrm{NO}$ via several metabolic reactions results in the formation of nitrite $\left(\mathrm{NO}_{2}^{-}\right)$and nitrate $\left(\mathrm{NO}_{3}^{-}\right)$as the two major end products [19]. The principal oxidation product of $\mathrm{NO}$ synthesis in aqueous solutions (in the absence of biological constituents such as hemoproteins) is $\mathrm{NO}_{2}^{-}$. The further oxidation to $\mathrm{NO}_{3}^{-}$requires the presence of additional oxidizing species such as oxyhemoproteins [20]. For example, NO is quickly oxidized to $\mathrm{NO}_{2}^{-}$via autoxidation in aqueous solutions, such as biological fluids, and may react with superoxide anions to produce peroxynitrites. In the presence of heme groups in proteins such as hemoglobin and myoglobin, NO reacts with oxyhemoglobin to produce metahemoglobin and $\mathrm{NO}_{3}^{-}$. Therefore, measurement of $\mathrm{NO}_{2}^{-}$and $\mathrm{NO}_{3}^{-}$in various biological fluids turned out to be the most suitable, practical and reliable non-invasive method to assess systemic NO synthesis in vivo [19].

\section{Plasma amino acids}

The amino acids L-arginine, L-citrulline and L-ornithine were analyzed as previously described by $\mathrm{Wu}$ and Meininger [21]. In brief, $50 \mu \mathrm{L}$ of plasma was mixed with 50 $\mu \mathrm{L}$ of $1.5 \mathrm{M}$ perchloric acid $(\mathrm{v} / \mathrm{v})$ to remove proteins. After $2 \mathrm{~min}$ at room temperature, $1.125 \mathrm{~mL} \mathrm{H}_{2} \mathrm{O}$ and 25 $\mu \mathrm{L}$ potassium carbonate was added. The tubes were 
centrifuged at $10000 \mathrm{~g}$ for $2 \mathrm{~min}$. The sample $(25 \mu \mathrm{L})$ was mixed with $25 \mu \mathrm{L}$ of the o-phthaldialdehyde (OPA) reagent solution $(\mathrm{v} / \mathrm{v})$ for $1 \mathrm{~min}$. The solution derivatized was immediately analyzed by HPLC. The HPLC device was equipped with a $3-\mu \mathrm{m}$ reversed-phase C18 column Kromasil $^{\circledR}(150 \times 4.6 \mathrm{~mm}$, I.D.) guarded by a $40-\mu \mathrm{m}$ reversed-phase $\mathrm{C} 18$ guard column Ascentis ${ }^{\circledR}(50 \mathrm{x}$ $4.6 \mathrm{~mm}, \mathrm{I} . \mathrm{D}$.) and a fluorescence detector model RF10AXL $\left(\right.$ Shimadzu ${ }^{\circledR}$ ) monitoring excitation and emission wavelengths at $340 \mathrm{~nm}$ and $455 \mathrm{~nm}$, respectively. These chromatographic methods are highly sensitive, specific, and accurate, as well as provide a useful tool to study the L-arginine-NO pathway.

\section{ADMA and SDMA analysis}

The plasma concentrations of ADMA and SDMA were analyzed as previously described by $\mathrm{Wu}$ and Meininger [21]. In brief, $200 \mu \mathrm{L}$ of plasma was mixed with $100 \mu \mathrm{L}$ of $1.5 \mathrm{M}$ perchloric acid (v/v) to remove proteins, followed by $50 \mu \mathrm{L}$ of $2 \mathrm{M}$ potassium carbonate and $700 \mu \mathrm{L}$ of phosphate buffer ( $\mathrm{pH}$ 7.0). The whole solution was loaded into a solid-phase extraction column (Oasis MCX) and the elution solvent was removed using a sample concentrator system (Savant SpeedVac Concentrator, Thermo Fisher Scientific Inc.). The residues were suspended in $200 \mu \mathrm{L}$ $\mathrm{H}_{2} \mathrm{O}$. The sample $(15 \mu \mathrm{L})$ was mixed with $15 \mu \mathrm{L}$ of the OPA reagent $(\mathrm{v} / \mathrm{v})$ for $1 \mathrm{~min}$. The solution derivatized was immediately analyzed by HPLC. The HPLC device was equipped with a Nucleosil 100-5 C6H5 column (250 x $4.6 \mathrm{~mm}$, I.D; Manchery Nagel, Easton, PA) and a fluorescence detector model RF-10AXL (Shimadzu ${ }^{\circledR}$ ) monitored excitation and emission wavelengths at $340 \mathrm{~nm}$ and $455 \mathrm{~nm}$, respectively. All chromatographic procedures were performed at room temperature.

\section{Statistical analysis}

A Two-way ANOVA with repeated measures on two factors $(2 \times 5$; group $\mathrm{x}$ time) was utilized to identify differences in NOx and plasma amino acids at each time point. Calculation of the integrated plasma NOx concentration [area under the curve (AUC)] was determined by the use of a trapezoidal method (baseline NOx concentration: $\mathrm{y}=0$ ). Unpaired Student $t$-test was utilized to identify differences in plasma concentrations of ADMA, SDMA and L-arginine/ADMA ratio at the onset of the study. Statistical significance was set at the 0.05 level of confidence. All analyses were performed using GraphPad Prism version 5.00 for Windows (GraphPad Software, San Diego California USA).

\section{Results}

\section{Subject characteristics}

At the study onset there were no significant differences between the randomly assigned placebo versus L- arginine groups with respect to age, height, body weight, BMI, body fat (see Table 1).

\section{Dietary control}

Based on the evaluation of the twenty-four-hour recall, all subjects of both the L-arginine and placebo groups had apparently adhered to the dietary orientation and avoided all foods listed as high in $\mathrm{NO}_{2}^{-}$and $\mathrm{NO}_{3}^{-}$. There was no significant difference in energy intake and percentage of macronutrients before $24 \mathrm{~h}$ of beginning the study between L-arginine and placebo groups $(2663 \pm 508.5$ vs $2905 \pm 641.6 \mathrm{kcal} ; 52.9 \pm 6.3$ vs $53.6 \pm 5.8 \%$ carbohydrates; $21.6 \pm 4.8$ vs $21.7 \pm 5.1 \%$ protein; $25.5 \pm 7.9$ vs $24.7 \pm 6.4 \%$ fat).

\section{Nitric oxide production}

Plasma $\mathrm{NO}_{2}^{-}+\mathrm{NO}_{3}^{-}$(NOx) concentrations at each time point are depicted in Figure 2. No significant differences were found between groups at any time point. Figure 3 presents the data for the total integrated NOx AUC during the $120 \mathrm{~min}$ post supplementation period. The integrated AUC revealed that despite a $15 \%$ higher, the L-arginine supplementation did not resulted in greater NOx response than placebo group over the time $(P>0.05)$.

\section{Plasma amino acids}

The plasma concentrations of L-arginine, L-citrulline and L-ornithine at each time point are depicted in Table 2. No significant difference between groups was observed at baseline. Plasma L-arginine increased significantly at $30 \mathrm{~min}(209.9 \pm 39.1$ vs $123.3 \pm 44.6 \mu \mathrm{mol} / \mathrm{L}, P<0.001)$, $60 \mathrm{~min}(192.3 \pm 51.3$ vs $133.4 \pm 36.0 \mu \mathrm{mol} / \mathrm{L}, P<0.05)$, $90 \mathrm{~min}(204.9 \pm 55.1$ vs $138.8 \pm 42.2 \mu \mathrm{mol} / \mathrm{L}, P<0.05)$ and $120 \mathrm{~min}(224.7 \pm 57.8$ vs $150.8 \pm 34.8 \mu \mathrm{mol} / \mathrm{L}, P<0.01)$ after supplementation in the L-arginine group, when compared to the placebo group (see Figure 4). No significant change was observed between groups in plasma Lcitrulline and $\mathrm{L}$-ornithine at any time point.

Table 1 Subject's baseline characteristics

\begin{tabular}{lcc}
\hline & L-Arg $(\mathbf{N}=\mathbf{9})$ & Pla $(\mathbf{N}=\mathbf{8})$ \\
\hline Age $(\mathrm{yr})$ & $26.0 \pm 4.6$ & $24.9 \pm 1.7$ \\
Height $(\mathrm{cm})$ & $175.4 \pm 7.7$ & $177.0 \pm 7.6$ \\
Body weight $(\mathrm{kg})$ & $79.3 \pm 12.5$ & $78.1 \pm 8.4$ \\
BMl $\left(\mathrm{kg} \cdot \mathrm{m}^{-2}\right)$ & $25.7 \pm 2.4$ & $24.9 \pm 2.3$ \\
Body fat $(\%)$ & $14.4 \pm 5.6$ & $16.4 \pm 2.5$ \\
ADMA $(\mu \mathrm{mol} / \mathrm{L})$ & $0.43 \pm 0.19$ & $0.39 \pm 0.15$ \\
L-arginine/ADMA ratio & $453 \pm 282$ & $438 \pm 272$ \\
SDMA ( $\mu$ mol/L) & $1.83 \pm 1.13$ & $1.70 \pm 0.62$ \\
\hline
\end{tabular}

The values are mean \pm standard deviation. $\mathrm{L}$-Arg $=\mathrm{L}$-arginine supplemented group; Pla = Placebo group. 


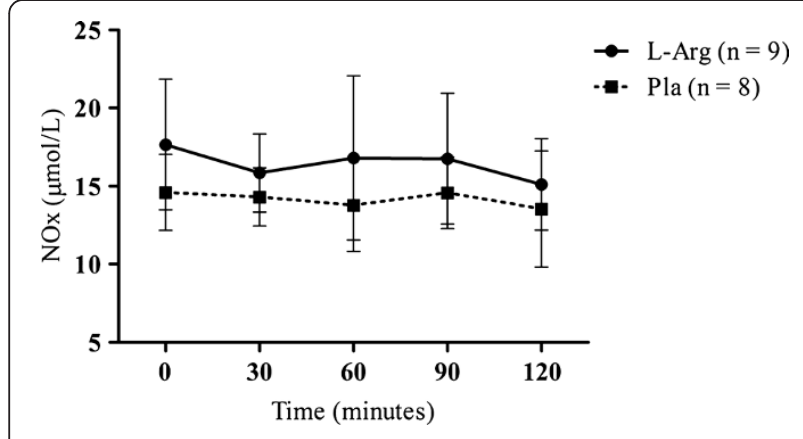

Figure 2 Plasma NOx concentrations ( $\mu \mathrm{mol} / \mathrm{L})$. No significant change was observed between groups at any time point. $\mathrm{L}-\mathrm{Arg}=\mathrm{L}-$ arginine supplemented group; Pla = Placebo group.

\section{Plasma ADMA and SDMA}

At the onset of the study, there were no significant differences in plasma levels of ADMA, SDMA and Larginine/ADMA ratio between the randomly assigned placebo versus L-arginine groups $(0.43 \pm 0.19$ vs $0.39 \pm 0.15 \mu \mathrm{mol} / \mathrm{L}$ and $1.83 \pm 1.13$ vs $1.70 \pm 0.62 \mu \mathrm{mol} / \mathrm{L})$ (see Table 1).

\section{Discussion}

Dietary supplements containing the semi-essential amino acid L-arginine (the only substrate of NOS) have been introduced in the market, claiming to promote vasodilatation by increasing production of NO. In the present study, we found that in healthy subjects $6 \mathrm{~g}$ of oral L-arginine supplementation did not stimulate an increase in NO production when compared with the placebo group. Additionally, no significant increases were observed in plasma L-citrulline, which is the by-product of NO synthesis from L-arginine. Furthermore, no significant differences in plasma concentrations of ADMA

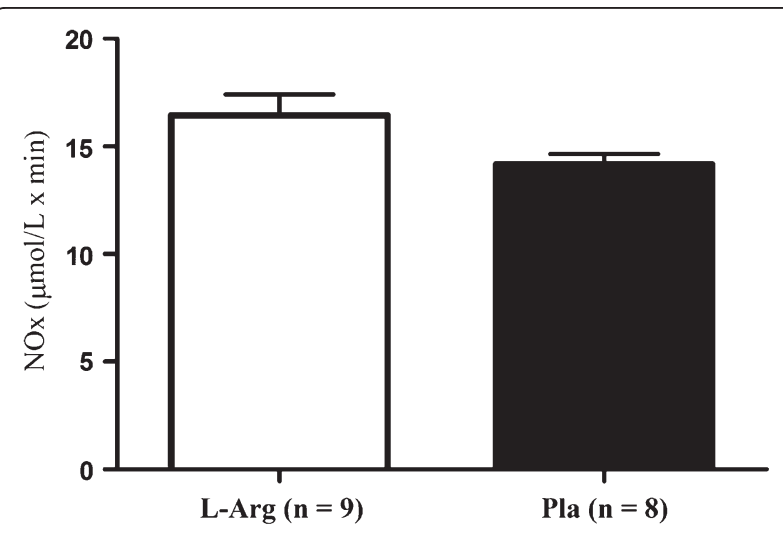

Figure 3 Total integrated NOx area under curve during the $120 \mathrm{~min}$ post supplementation period. No significant change was observed between groups over the time. $L$-Arg $=L$-arginine supplemented group; Pla = Placebo group. and SDMA at onset of the study were observed between the L-arginine and placebo groups.

Several studies had showed no significant difference in $\mathrm{NO}$ production (measured by $\mathrm{NO}_{2}^{-}$and $\mathrm{NO}_{3}^{-}$) after Larginine supplementation [22-24]. Liu et al. [22] did not observe any significant differences in plasma $\mathrm{NO}_{2}^{-}$and $\mathrm{NO}_{3}^{-}$concentrations after orally supplementing ten healthy male athletes with $6 \mathrm{~g}$ of L-arginine (as free form) or placebo for 3 days. Koppo et al. [23] observed no significant difference in urinary $\mathrm{NO}_{2}^{-}$and $\mathrm{NO}_{3}^{-}$after 14 days of supplementing seven physically active healthy males with $7.2 \mathrm{~g}$ of L-arginine hydrochloride $(3 \times 3$ capsules of $805 \mathrm{mg}$ ), and Tang et al. [24] also did not observed any significant difference on NO synthesis (measured by plasma $\mathrm{NO}_{2}^{-}$and $\mathrm{NO}_{3}^{-}$) in eight healthy young men after an single dose of $10 \mathrm{~g}$ of L-arginine. Since all subjects of these studies were submitted to exercise, the results of these studies are not surprising due to the very nature of the underlying mechanism of NO synthesis: vascular shear stress is considered the main stimulus for endothelial NO production during exercise [25]. Therefore, there should theoretically be no need for supplementary L-arginine to synthesize NO during exercise.

Regarding studies at rest condition, Blum et al. [26] investigated the effects of oral L-arginine ( $9 \mathrm{~g}$ daily for one month) on NO bioactivity in 10 healthy postmenopausal women. After the supplementation period, the authors observed no significant difference in serum $\mathrm{NO}_{2}^{-}$ and $\mathrm{NO}_{3}^{-}$concentrations. In another study, Evans et al. [27] also did not find significant differences in serum $\mathrm{NO}_{2}^{-}$and $\mathrm{NO}_{3}^{-}$concentrations after submitting twelve healthy subjects to take L-arginine for 1-week periods at daily doses of 3, 9, 21, and 30 g. Schwedhelm et al., [28] published a study with the purpose of investigating the pharmacokinetic and pharmacodynamics properties of oral L-arginine with regard to NO metabolism. Twenty healthy subjects were submitted to two doses of Larginine supplementation (1 $\mathrm{g}$ of arginine sustainedrelease tree times per day or $1.6 \mathrm{~g}$ of immediate-release arginine two times per day) for 7 days. At baseline and on day 7 , a single dose of L-arginine supplementation (half of the total daily dose, respectively) was administered and blood samples were drawn at $0,0.5,1,2,3,4$, $6,8,12,16$ and $24 \mathrm{~h}$ after supplementation. The authors observed no significant differences in urinary excretion of nitrate at any time point, despite increases in plasma L-arginine concentrations after the supplementation $\left(\mathrm{T}_{\max }=3.7 \pm 1.3 \mathrm{~h}\right.$ for arginine sustained-release and $0.7 \pm 0.1 \mathrm{~h}$ for arginine immediate-release). In the present study, the plasma L-arginine concentrations increased significantly after $30 \mathrm{~min}$ of L-arginine supplementation when compared to placebo group, and maintained high throughout the study period. Furthermore, 
Table 2 Values of plasma amino acids ( $\mu \mathrm{mol} / \mathrm{L})$ at $-10,30,60,90$ and 120 minutes post-supplementation

\begin{tabular}{|c|c|c|c|c|c|c|c|c|c|c|}
\hline \multirow[t]{2}{*}{ Amino acid } & \multicolumn{5}{|c|}{ L-Arg ( $n=9)$} & \multicolumn{5}{|c|}{ Pla $(n=8)$} \\
\hline & -10 & 30 & 60 & 90 & 120 & -10 & 30 & 60 & 90 & 120 \\
\hline \multirow[t]{2}{*}{ L-citrulline } & 57.4 & 125.2 & 75.2 & 89.7 & 82.2 & 56.2 & 76.9 & 66.2 & 75.9 & 79.8 \\
\hline & \pm 31.2 & \pm 136.3 & \pm 45.4 & \pm 92.9 & \pm 78.0 & \pm 28.1 & \pm 26.3 & \pm 43.0 & \pm 53.9 & \pm 63.0 \\
\hline \multirow[t]{2}{*}{ L-arginine } & 151.7 & 209.9 & 192.3 & 204.9 & 224.7 & 146.2 & 123.3 & 133.4 & 138.8 & 150.8 \\
\hline & \pm 33.9 & $\pm 39.1^{* * *}+$ & $\pm 51.3^{*}$ & $\pm 55.1^{*}$ & $\pm 57.8^{* a}$ & \pm 44.3 & \pm 44.6 & \pm 36.0 & \pm 42.2 & \pm 34.8 \\
\hline \multirow[t]{2}{*}{ L-ornithine } & 127.5 & 153.2 & 154.0 & 143.1 & 147.0 & 93.4 & 119.8 & 101.1 & 105.5 & 110.4 \\
\hline & \pm 87.1 & \pm 84.9 & \pm 65.7 & \pm 55.9 & \pm 65.4 & \pm 23.7 & \pm 88.8 & \pm 49.6 & \pm 59.9 & \pm 59.2 \\
\hline
\end{tabular}

The values are mean \pm standard deviation. The symbols ${ }^{* * *}(P<0.001),{ }^{* *}(P<0.01)$ and ${ }^{*}(P<0.05)$ denotes significantly different from placebo at same time point; ${ }^{a}$ denotes significantly different from time -10 . L-Arg = L-arginine supplemented group; Pla = Placebo group.

no significant differences were observed in plasma concentrations of L-ornithine and L-citrulline at any time point between the groups.

It is important to point out that, contrary to the present study, neither of the above mentioned studies controlled the intake of food rich in $\mathrm{NO}_{2}^{-}$and $\mathrm{NO}_{3}^{-}$from subject's diet before or during the study. Most $\mathrm{NO}_{2}^{-}$and $\mathrm{NO}_{3}^{-}$comes from diet (vegetable products contain the highest levels of $\mathrm{NO}_{3}^{-}$; meat and bean products contain the highest levels of $\mathrm{NO}_{2}^{-}$), which may alter the results of the analysis. Thus, endogenous synthesis of NO may not be adequately measured by $\mathrm{NO}_{2}^{-}$and $\mathrm{NO}_{3}^{-}$in plasma and urine if the diet is not controlled.

Measurement of $\mathrm{NO}_{2}^{-}$and $\mathrm{NO}_{3}^{-}$in various biological fluids turned out to be the most suitable, practical and reliable non-invasive method to assess systemic NO synthesis in vivo [19]. In the present study, $\mathrm{NO}$ synthesis was quantified by measuring plasma $\mathrm{NO}_{2}^{-}+\mathrm{NO}_{3}^{-}(\mathrm{NOx})$ via high-performance liquid chromatography. Most of the studies [22-24] had analyzed NO synthesis by using Griess reaction. The acidic conditions under which experiments using Griess reaction are conducted favor the formation of S-nitroso compounds from $\mathrm{NO}_{2}^{-}$and reduced thiols. Thus, the measurement of $\mathrm{NO}_{2}^{-}$and $\mathrm{NO}_{3}^{-}$ in biological fluids by assays based on the Griess is

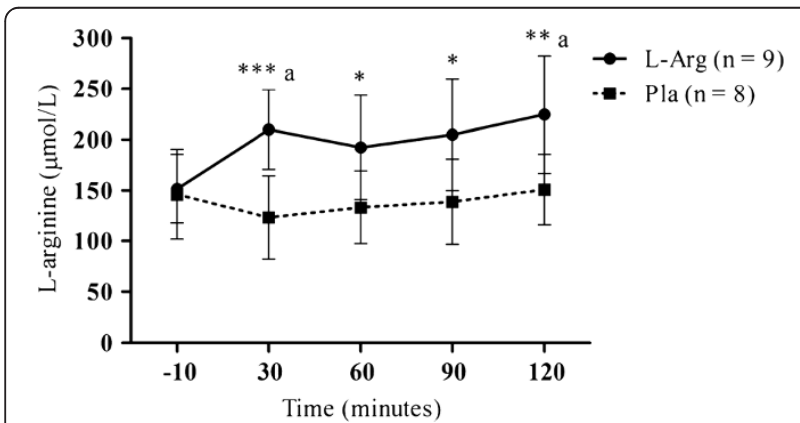

Figure 4 Plasma concentration of $\mathrm{L}$-arginine. The symbols *** $(P<0.001), * *(P<0.01)$ and ${ }^{*}(P<0.05)$ denotes significantly different from placebo; ${ }^{a}(P<0.01)$ denotes significantly different from 0 minutes. $\mathrm{L}$-Arg $=\mathrm{L}$-arginine supplemented group; $\mathrm{Pla}=$ Placebo group. subject to interference by many substances acting at different places in the Griess reaction and the following spectrophotometric measurement in the same wavelength (normal absorbance at $540 \mathrm{~nm}$ ). Therefore, studies using Griess reaction to detect stable metabolites $\left(\mathrm{NO}_{2}^{-}\right.$and $\left.\mathrm{NO}_{3}^{-}\right)$to measure $\mathrm{NO}$ synthesis may have significant methodological limitations, as compared to fluorometric techniques associated with HPLC.

Bailey et al. [11] observed significant increases in plasma $\mathrm{NO}_{2}^{-}$after supplementing nine healthy recreationally active men with a supplement that contained $6 \mathrm{~g}$ of L-arginine (dissolved in $500 \mathrm{~mL}$ of water) as compared to placebo. It is important to note that this study associated other amino acids besides L-arginine, including L-citrulline (quantities not expressed in the study), which have been shown to increase NO production, as measured by plasma concentrations of $\mathrm{NO}_{2}^{-}$[29] and urinary excretion of $\mathrm{NO}_{3}^{-}$and cGMP [28]. Interestingly, the authors did not measure plasma $\mathrm{NO}_{2}^{-}$at baseline; they had just done so 1 hour after supplementation, which is a major methodological limitation, since it is not known whether there were any differences in the samples prior to supplementation. Furthermore, taking into consideration that diet can influence nitrite plasma concentrations, no dietary control to limit the consumption of foods rich in $\mathrm{NO}_{2}^{-}$and $\mathrm{NO}_{3}^{-}$was conducted.

Others studies also have showed improvements in NO production by using L-arginine supplementation [30-33]. However, all of these studies had administered L-arginine in subjects with some cardiovascular risk factors or cardiopathy. It appears that L-arginine is a limiting factor for NO synthesis in patients at risk for atherosclerosis, but not for healthy individuals [34]. Therefore, Larginine supplementation may be necessary only for individuals with atherosclerosis risk factors.

Among the possible explanations for this phenomenon is the presence of high levels of asymmetric dimethylarginine (ADMA), an endogenous NOS inhibitor. Higher concentrations of ADMA were encountered in individuals with atherosclerosis, as well as in individuals with atherosclerosis risk factors, such as hypercholesterolaemia, 
hypertension, diabetes mellitus, kidney failure, hyperhomocysteinaemia, smoking and aging [10]. Physiological levels of L-arginine and the presence of normal concentrations of ADMA saturate the endothelial NOS enzyme, promoting $\mathrm{NO}$ production. In these conditions, Larginine supplementation does not affect enzyme activity. In contrast, in the presence of elevated plasma concentrations of ADMA the endothelial NOS activity diminishes, resulting in lower physiological levels of NO production. SDMA has no effect on NOS activity but may compete with L-arginine for the $y+$ transport system [35]. Under these conditions, L-arginine supplementation may reestablish the L-arginine/ADMA ratio in order to activate endothelial NOS [4]. Therefore, L-arginine supplementation may exert a beneficial effect on vascular function.

In the present study, we observed no significant difference in plasma concentrations of ADMA, SDMA and Larginine/ADMA ratio at baseline between the groups. This finding may explain the absence of significant changes in NO production after L-arginine supplementation. The baseline plasma concentrations of ADMA observed in the present study are similar to previous studies in healthy subjects which reported ADMA concentrations ranging between 0.3 and $0.9 \mu \mathrm{mol} / \mathrm{L}$ [36-38]. Therefore, it may be speculated that there should be no further increase in NO production after L-arginine supplementation in subjects with normal levels of ADMA.

Böger et al., [34] observed that plasma ADMA levels were significantly higher in hypercholesterolemic subjects than in normocholesterolemic control subjects $(2.17 \pm 0.15$ and $1.03 \pm 0.09 \mu \mathrm{mol} / \mathrm{L}$, respectively); and the higher levels of ADMA was associated with reduced NO synthesis. Therefore, it appears that high plasma ADMA concentrations may inhibit NOS enzyme, but low or normal plasma ADMA concentrations do not affect NO synthesis.

In conclusion, L-arginine supplementation does not increase NO production in healthy subjects with normal plasma ADMA concentrations. Therefore, it is not advisable to recommend dietary supplements containing L-arginine for the purposes of increasingacutely NO production in healthy subjects. This result does not discard the possible effect of $\mathrm{L}$-arginine on $\mathrm{NO}$ production in individuals with pathophysiologicalconditions (e.g.: hypercholesterolaemia, hypertension, diabetes mellitus, kidney failure, hyperhomocysteinaemia, smoking and aging) and long-term studies are needed to identify whether L-arginine may provide some benefit.

\section{Abbreviations}

NO: Nitric oxide; NOS: Nitric oxide synthase; NOx: Nitrite + nitrate; $\mathrm{NO}_{2}^{-}$: Nitrite; $\mathrm{NO}_{3}^{-}$: Nitrate; HPLC: High-performance liquid chromatography;

ANOVA: Analysis of variance; ADMA: Asymmetric dimethylarginine;

SDMA: Symmetric dimethylarginine

\section{Competing interests}

Each author certifies that he or she has no commercial associations (e.g., consultancies, stock ownership, equity interest, patent/licensing arrangements, etc.) that might pose a conflict of interest in connection with the submitted article, except as disclosed on a separate attachment. All funding sources supporting the Work and all institutional or corporate affiliations of the authors are acknowledged in a footnote in the Work.

\section{Authors' contributions}

TSA contributed substantially to data acquisition and chromatographic analysis, statistical analysis and data interpretation, and was the manuscript writer. CACJ contributed substantially to chromatographic analysis, interpretation of results, and reviewing the manuscript. JTS contributed to data interpretation and manuscript revision. VMFP contributed to data interpretation and manuscript revision. All authors read and approved the final manuscript.

\section{Acknowledgements}

This work was supported by a grant from The Research Foundation of the State of Rio de Janeiro - FAPERJ (grant No. E-26/102.384/2009). TS Alvares received a research productivity scholarship from CNPq (No. 382295/2010-2). The authors would like to thank Ricky Toledano for the preparation of the English version of the manuscript.

Received: 20 December 2011 Accepted: 16 May 2012

Published: 12 June 2012

\section{References}

1. Kreider RB, Wilborn CD, Taylor L, Campbell B, Almada AL, Collins R, Cooke M, Earnest CP, Greenwood M, Kalman DS, Kerksick CM, Kleiner SM, Leutholtz B, Lopez H, Lowery LM, Mendel R, Smith A, Spano M, Wildman R, Willoughby DS, Ziegenfuss TN, Antonio J: ISSN Exercise \& Sport Nutrition Review: Research \& Recommendations. J Int Soc Sports Nutr 2010, 7:7.

2. Alvares TS, Meirelles CM, Bhambhani YN, Paschoalin VM, Gomes PS: L-arginine as a Potential Ergogenic Aid in Healthy Subjects. Sports Med 2011, 41(3):233-248.

3. Appleton J: Arginine: Clinical potential of a semi-essential amino. Altern Med Rev 2002, 7(6):512-522.

4. Bode-Böger SM, Scalera F, Ignarro LJ: The L-arginine paradox: importance of the L-arginine/asymmetrical dimethylarginine ratio. PharmacolTher 2007, 114(3):295-306.

5. Creager M, Gallagher S, Girerd X, Coleman S, Dzau V, Cooke J: L-Arginine improves endothelium-dependent vasodilation in hypercholesterolemic humans. J Clin Invest 1992, 90(4):1248-1253.

6. Clarkson P, Adams M, Powe A, Donald A, McCredie R, Robinson J, McCarthy $\mathrm{S}$, Keech A, Celermajer D, Deanfiel J: Oral L-Arginnine improves endothelium-dependent dilation in hypercholesterolemic young adults. J Clin Invest 1996, 97(8):1989-1994.

7. Pieper G, Siebeneich W, Dondlinger L: Short-term oral administration of L-arginine reverses defective endothelium-dependent relaxation and cGMP generation in diabetes. Eur J Pharmacol 1996, 317(2-3):317-320.

8. Adams M, McCredie R, Jessup W, Robinson J, Sullivan D, Celermajer D: Oral L-Arginine improves endothelium-dependent dilatation and reduces monocyte adhesion to endothelial cells in young men with coronary artery disease. Atherosclerosis 1997, 129(2):261-269.

9. Lerman A, Burnett J Jr, Higano S, McKinley L, Holmes D Jr: Long-term L-Arginine supplementation improves small-vessel coronary endothelial function in humans. Circulation 1998, 97(21):2123-2128.

10. Böger R: Asymmetric Dimethylarginine, an Endogenous Inhibitor of Nitric Oxide Synthase, Explains the "L-Arginine Paradox" and Acts as a Novel Cardiovascular Risk Factor. J Nutr 2004, 134(10):2842S-2847S.

11. Bailey SJ, Winyard PG, Vanhatalo A, Blackwell JR, DiMenna FJ, Wilkerson DP, Jones AM: Acute L-arginine supplementation reduces the $\mathrm{O} 2$ cost of moderate-intensity exercise and enhances high-intensity exercise tolerance. J Appl Physiol 2010, 109(5):1394-1403.

12. Stevens BR, Godfrey MD, Kaminski TW, Braith RW: High-intensity dynamic human muscle performance enhanced by a metabolic intervention. Med Sci Sports Exerc 2000, 32(12):2102-2108.

13. Buford BN, Koch AJ: Glycine-arginine-alpha-ketoisocaproic acid improves performance of repeated cycling sprints. Med Sci Sports Exerc 2004, 36(4):583-587. 
14. Bode-Böger SM, Muke J, Surdacki A, Brabant G, Böger RH, Frölich JC: Oral $\mathrm{L}$-arginine improves endothelial function in healthy individuals older than 70 years. Vasc Med 2003, 8(2):77-81.

15. Forbes SC, Bell GJ: The acute effects of a low and high dose of oral $\mathrm{L}$-arginine supplementation in young active males at rest. Appl Physiol Nutr Metab 2011, 36(3):405-411.

16. Griesenbeck JS, Steck MD, Huber JC Jr, et al: Development of estimates of dietary nitrates, nitrites, and nitrosamines for use with the short Willet food frequency questionnaire. Nutr J 2009, 6:8-16.

17. Bode-Böger SM, Böger RH, Galland A, Tsikas D, Frölich JC: L-arginine-induced vasodilation in healthy humans: pharmacokineticpharmacodynamic relationship. Br J Clin Pharmacol 1998, 46(5):489-497.

18. Li H, Meininger $\mathrm{CJ}, \mathrm{Wu} \mathrm{G}$ : Rapid determination of nitrite by reversedphase high-performance liquid chromatography with fluorescence detection. J Chromatogr B Biomed Sci Appl 2000, 746(2):199-207.

19. Tsikas D: Methods of quantitative analysis of the nitric oxide metabolites nitrite and nitrate in human biological fluids. Free Radic Res 2005, 39(8):797-815.

20. Ignarro LJ, Fukuto JM, Griscavage JM, Rogers NE, Byrns RE: Oxidation of nitric oxide in aqueous solution to nitrite but not nitrate: Comparison with enzymatically formed nitric oxide from L-arginine. Proc Natl Acad Sci USA 1993, 90(17):8103-8107.

21. $W u$ G, Meininger CJ: Analysis of Citrulline, Arginine, and Methylarginines using High-Performance Liquid Chromatography. Methods Enzymol 2008, 440:177-189.

22. Liu TH, Wu CL, Chiang CW, Lo YW, Tseng HF, Chang CK: No effect of shortterm arginine supplementation on nitric oxide production, metabolism and performance in intermittent exercise in athletes. J NutrBiochem 2009, 20(6):462-468

23. Koppo K, Taes YE, Pottier A, Boone J, Bouckaert J, Derave W: Dietary arginine supplementation speeds pulmonary VO2 kinetics during cycle exercise. Med Sci Sports Exerc 2009, 41(8):1626-1632.

24. Tang JE, Lysecki PJ, Manolakos JJ, MacDonald MJ, Tarnopolsky MA, Phillips SM: Bolus arginine supplementation affects neither muscle blood flow nor muscle protein synthesis in young men at rest or after resistance exercise. J Nutr 2011, 141(2):195-200.

25. Hickner RC, Fisher JS, Ehsani AA, Kohrt WM: Role of nitric oxide in skeletal muscle blood flow at rest and during dynamic exercise in humans. Am J Physiol 1997, 273(1 Pt 2):H405-H410.

26. Blum A, Hathaway L, Mincemoyer R, Schenke WH, Kirby M, Csako G, Waclawiw MA, Panza JA, Cannon RO 3rd: Effects of oral L-arginine on endothelium-dependent vasodilation and markers of inflammation in healthy postmenopausal women. J Am CollCardiol 2000, 35(2):271-276.

27. Evans RW, Fernstrom JD, Thompson J, Morris SM Jr, Kuller LH: Biochemical responses of healthy subjects during dietary supplementation with Larginine. J Nutr Biochem 2004, 15(9):534-539.

28. Schwedhelm E, Maas R, Freese R, Jung D, Lukacs Z, Jambrecina A, Spickler W, Schulze F, Böger RH: Pharmacokinetic and pharmacodynamic properties of oral L-citrulline and L-arginine: impact on nitric oxide metabolism. Br J Clin Pharmacol 2008, 65(1):51-59.

29. Sureda A, Cordova A, Ferrer MD, et al: Effects of L-citrulline oral supplementation on polymorphonuclear neutrophils oxidative burst and nitric oxide production after exercise. Free Radic Res 2009, 43(9):828-835.

30. Koifman B, Wollman $Y$, Bogomolny $N$, Chernichowsky T, Finkelstein A, Peer G, Scherez J, Blum M, Laniado S, laina A, Keren G: Improvement of cardiac performance by intravenous infusion of L-arginine in patients with moderate congestive heart failure. J Am Coll Cardiol 1995, 26(5):1251-1256.

31. Böger RH, Bode-Böger SM, Thiele W, Creutzig A, Alexander K, Frölich JC: Restoring vascular nitric oxide formation by L-arginine improves the symptoms of intermittent claudication in patients with peripheral arterial occlusive disease. J Am Coll Cardiol 1998, 32(5):1336-1344.

32. Piatti P, Fragasso G, Monti LD, Setola E, Lucotti P, Fermo I, Paroni R, Galluccio E, Pozza G, Chierchia S, Margonato A: Acute intravenous Larginine infusion decreases endothelin-1 levels and improves endothelial function in patients with angina pectoris and normal coronary arteriograms: correlation with asymmetric dimethylarginine levels. Circulation 2003, 107(3):429-436.

33. Lucotti P, Setola E, Monti LD, Galluccio E, Costa S, Sandoli EP, Fermo I, Rabaiotti G, Gatti R, Piatti P: Beneficial effects of a long-term oral Larginine treatment added to a hypocaloric diet and exercise training program in obese, insulin-resistant type 2 diabetic patients. Am J Physiol Endocrinol Metab 2006, 291(5):E906-E912.

34. Böger RH, Bode-Böger SM, Szuba A, Tsao PS, Chan JR, Tangphao O, Blaschke TF, Cooke JP: Asymmetric dimethylarginine (ADMA): a novel risk factor for endothelial dysfunction: its role in hypercholesterolemia. Circulation 1998, 98(18):1842-1847.

35. Tsikas D, Böger RH, Sandmann J, Bode-Böger SM, Frölich JC: Endogenous nitric oxide synthase inhibitors are responsible for the L-arginine paradox. FEBS Lett 2000, 478(1-2):1-3.

36. Hov GG, Sagen E, Bigonah A, Asberg A: Health-associated reference values for arginine, asymmetric dimethylarginine (ADMA) and symmetric dimethylarginine (SDMA) measured with high-performance liquid chromatography. Scand J Clin Lab Invest 2007, 67(8):868-876.

37. Teerlink T: Measurement of asymmetric dimethylarginine in plasma: methodological considerations and clinical relevance. Clin Chem Lab Med 2005, 43(10):1130-1138.

38. Horowitz JD, Heresztyn $\mathrm{T}$ : An overview of plasma concentrations of asymmetric dimethylarginine (ADMA) in health and disease and in clinical studies: methodological considerations. J Chromatogr B Analyt Technol Biomed Life Sci 2007, 851(1-2):42-50.

doi:10.1186/1743-7075-9-54

Cite this article as: Alvares et al:: Acute L-Arginine supplementation does not increase nitric oxide production in healthy subjects. Nutrition \& Metabolism 2012 9:54

\section{Submit your next manuscript to BioMed Central and take full advantage of:}

- Convenient online submission

- Thorough peer review

- No space constraints or color figure charges

- Immediate publication on acceptance

- Inclusion in PubMed, CAS, Scopus and Google Scholar

- Research which is freely available for redistribution 